\title{
ALOKASI PENGGUNAAN REMITTANCE TENAGA KERJA WANITA (TKW) DAN DAMPAKNYA TERHADAP KESEJAHTERAAN MASYARAKAT DESA JOROK KECAMATAN UTAN
}

\author{
Fitriah Permata Cita ${ }^{{ }^{*}}$, Muhammad Nurjihadi ${ }^{2}$, Onny Liesmayanti ${ }^{3}$ \\ Program Studi Ekonomi Pembangunana Fakultas Ekonomi dan Bisnis \\ Universitas Teknologi Sumbawa \\ ${ }^{*}$ Corresponding Author email: ${ }^{1}$ fitriahpermatacita40@yahoo.com.id
}

\section{Diterima}

Bulan Oktober 2019

\section{Diterbitkan \\ Bulan Oktober 2019}

Keyword: Remittance, Tenaga Kerja Wanita, Kesejahtraan

Abstrak

Skripsi ini bertujuan untuk mengetahui alokasi pengunaan remitansi tenaga kerja wanita terhadap tingkat kesejahteraan masyarakat dan dari alokasi tersebut jenis alokasi mana yang memberi dampak terhadap kesejahteraan masyarakat. Penelitian ini menggunakan dua metode analisis yaitu analisis kualitatif dengan pendekatan deskriftif dan analisis hirarki proses dengan pengumpulan data dengan cara wawancara. Objek penelitian berjumlah 50 orang dari mantan TKW atau keluarga TKW yang ditentukan dengan cara Convenience sampling. Objek ke dua berjumlah 15 orang pakar yaitu akademisi yang mengerti tentang kesejahteraan dan ditentukan dengan cara purposive sampling. Lokasi penelitian terletak di Desa Jorok Kecamatan Utan Kabupaten Sumbawa. Berdasarkan analisa data yang telah dilakukan didapatkan hasil penelitian bahwa ada dua jenis kategori penggunaan remittance yaitu konsumtif dan produktif, dari penggunaan produktif TKW mengalokasikan dana remittance untuk pendidikan, beli tanah, hewan ternak dan usaha. Sedangkan untuk penggunaan konsumtif yaitu pemenuhan kebutuhan sehari-hari, kendaraan, bayar hutang dan renovasi rumah. Jika dibandingkan dari setiap kriteria penggunaan produktif, beli tanah merupakan penggunaan yang paling mempengaruhi TKW dalam menggunakan dana remittance dan bersifat jangka panjang. Untuk penggunaan konsumtif, kebutuhan sehari-hari merupakan penggunaan yang paling memberi dampak pada kesejahteraan TKW jangka pendek.
\end{abstract}

\section{PENDAHULUAN}

Indonesia merupakan negara dengan jumlah penduduk terbanyak nomor empat di dunia setelah Tiongkok, India dan Amerika Serikat. Tingginya laju pertumbuhan penduduk dari tahun ke tahun berdampak terhadap masalah-masalah pengangguran, kemiskinan, serta adanya pelaku migrasi (Triani,2012). Badan Pusat Statistik [BPS] (2018) mencatat laju pertumbuhan penduduk dapat dilihat dari meningkatnya jumlah penduduk dari tahun ke tahun, seperti pada tahun 2016 jumlah penduduk indonesia 257.9 juta jiwa, pada tahun 2017 meningkat menjadi 262.8 juta jiwa dan pada tahun 2018 Jumlah tersebut terus meningkat mencapai 2.66.7 juta jiwa. Sebagai mana yang dikatakan Hadisumarto (1995) dalam bukunya zaman modern sekarang ini membawa pengaruh terhadap urbaniasi atau fakror yang mempengaruhi urbanisasi yaitu meningkatnya jumlah penduduk suatu daerah, meningkatnya kepadatan penduduk dan dalam waktu yang sama juga membuat perbedaan secara bertingkat sosial penduduk. Urbanisasi merupakan perpindahan penduduk dari desa ke kota yang di latar belakangi oleh fakor sosial, ekonomi, politik dan budaya (Hadisumarto, 1995). Fenomena urbanisasi berdampak terhadap meningkatnya jumlah pelaku migrasi, seperti yang dikatakan Mantra (1985) migrasi merupakan perubahan tempat tinggal yang melampaui batas-batas wilayah yang telah ditetapkan atau disepakati selama beberapa kurun waktu dari suatu wilayah ke wilayah lain dengan maksud untuk menetap di daerah tujuan. Migrasi berkembang karna perbedaan antara perhitungan pendapatan di pedesaan tidak sesuai dengan apa yang diharapkan dan yang terjadi melakukan migrasi jika pendapatan yang diharapkan lebih besar di kota atau luar negri lebih besar dari pada rata-rata pendapatan di pedesaan maupun kemudahan untuk memperoleh fasilitas tertentu(Todaro,1969). Faktor terjadinya migrasi di pedesaan seperti yang dikemukakan oleh Mantra(1985) bahwa faktor yang mendorong penduduk untuk meninggalkan desa antara lain karena penghasilan di desa relatif rendah, pekerjaan di bidang pertanian relatif kurang dan tidak punya tanah garapan yang memadai.

Nusa Tenggara Barat merupakan salah satu pengirim Tenaga Kerja Indonesia di Indonesia. Badan Nasional Penempatan dan Perlindungan 
Tenaga Kerja Indonesia [BNP2TKI] (2018) mencatat kabupaten tertinggi pengirim TKI pada priode 2017 Januari-Desember, ada 5 kabupaten tertinggi pengirim TKI di Indonesia, yang pertama ada Jawa Timur, kedua Jawa Tengah, ketiga Jawa Barat, keempat NTB dan yang kelima lampung, dari kelima kabupaten tesebut NTB merupakan Provinsi keempat tertinggi dari 5 Provinsi pengirim TKI terbanyak di Indonesia setelah Jawa Timur, Jawa Tengah dan Jawa Barat.

Pasal 1 bagian (1) undang-undang nomor 39 tahun 2004 tentang Penempatan dan Perlindungan Tenaga Kerja Indonesia di Luar Negeri, TKI adalah setiap wanita atau laki-laki yang mampu melakukaan pekerjaan, baik di dalam maupun diluar hubungan kerja, guna menghasilkan sesuatu yang berupa barang atau jasa untuk memenuhi kebutuhan sendiri atau masyarakat. Peningkatan pengiriman TKI berdampak pada meningkatnya jumlah remitansi atau pengirimanan uang. Remitansi adalah uang yang dikirim oleh pelaku migrasi dari negara tujuan ke negara asalnya (International Monetery Found,2008). adanya remitansi akan dimanfaatkan untuk beberapa tujuan seperti yang katakan oleh Haryati (2006 ) remitansi dari TKI digunakan untuk kegiatan konsumtif yaitu untuk memenuhi kebutuhan sehari-hari dan kegiatan produktif yaitu dengan melalui pendidikan anak maupun investasi.

Remitansi yang dikirimkan dari luar negeri memberikan peranan yang cukup besar bagi keluarga TKI dan juga daerah asal, dana remitansi yang masuk ke NTB mampu meningkatkan daya beli masyarakat dikarnakan pendapatan TKI yang meningkat, apabila di salurkan ke suatu bidang usaha maka akan berdampak terhadap pertumbuhan ekonomi di daerah asal termasuk memberikan dampak positif sebagai peningkatan keuangan inklusif yang berpengaruh pada jumlah orang yang menjadi nasabah atau pengguna jasa keuangan Indonesia (Haryati,2006).

Bank Indonesia [BI] (2018) mencatat dana remitansi yang masuk ke NTB setiap tiga bulan sekali pada tahun 2017 mencapai 348 miliar, jika dilihat pertahunnya mencapai 1.392 triliun rupiah dan pada tahun 2016 mencapai 475 miliar rupiah setiap tiga bulan sekali dan pertahunnya mencapai 1.900 triliun rupiah. Tingginya jumlah remitansi tenaga kerja luar negeri juga berpengaruh tehadap tingginya jumlah devisa yang masuk ke kas negara (Priambada,2014). Saat terjadi remintansi dari luar negeri TKI harus membeli rupiah dengan menggunakan mata uang asing, banyaknya mata uang asing yang ditukarkan akan berakibat pada dua hal yaitu bertambahnya simpanan uang asing yang menjadi sumber devisa dan kebutuhan rupiah meningkat, sesuai dengan hukum permintaan dan penawaran maka nilai mata uang rupiah akan menguat dibanding mata uang asing ( Jandika,2017). Kabupaten Sumbawa merupakan salah satu penyumbang TKI Provinsi NTB.

Grafik 1.1 Jumlah pengiriman TKI di Kabupaten Sumbawa tahun 2013-2017

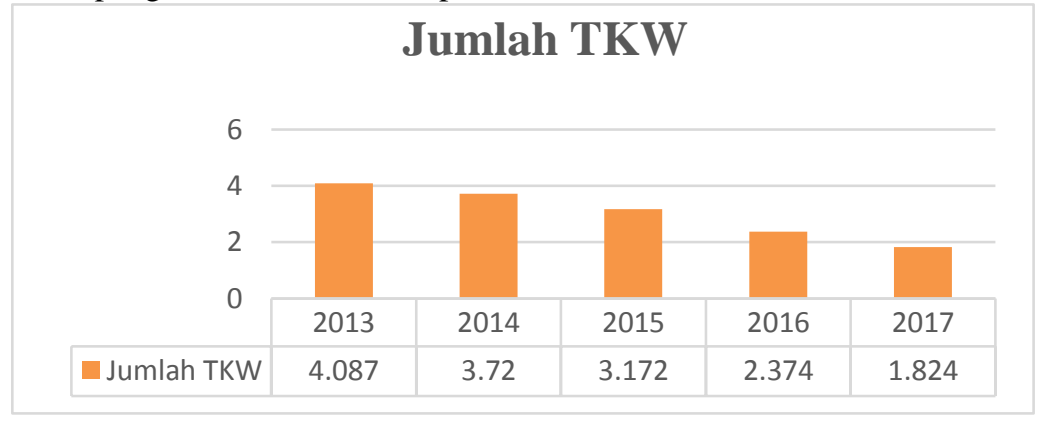

Sumber: Badan Pusat Statistik [BPS] 2018

Diagram diatas menunjukan bahwa pengiriman TKW dari tahun 2013-2014 cenderung menurun. Jumlah TKI dari tahun ke tahun cendrung menurun disebabkan oleh terciptanya lapangan kerja di dalam negeri yang memberi kesempatan untuk berkerja kepada penduduk usia kerja didukung oleh zaman yang semakin modern yang memudahkan pencari kerja untuk belajar berwirausaha secara mandiri dan para TKI diuar negeri memilih merubah gaya hidup pasca pulang ke daerah asal karna faktor usia dan modal yang telah di dapatkan (Octaviani,2017).
Kemiskinan di berbagai pelosok daerah khususnya pedesaan di Kabupaten Sumbawa membuat masyarakat pedesaan memilih untuk berkerja sebagai TKI di luar negeri, selain untuk memperbaiki taraf hidup keluarga TKI dana remitansi TKI dari luar negeri mampu menekan angka kemiskinan di daerah asal khususnya di pedesaan ( Novianti,2009).

Penelitian sebelumnya yang dilakukan oleh Hamida pada tahun 2013 adalah tentang dampak remitansi TKI luar negeri pada peningkatan investasi di pedesaan bahwa kegiatan konsumtif 
cenderung mereka gunakan untuk biaya kehidupan sehari-hari seperti keperluan makan dan minum, belanja barang habis pakai dan lain-lain dan jika di lihat untuk kegiatan produktif TKW di pedesaan cenderung mengunakan uangnya untuk melakukan investasi seperti membangun kios-kios kecil, membeli tanah, pendidikan anak dan modal untuk kegiatan usaha lainnya. Apabila di Breakdwon Perkecamatan, Kecamatan Utan Kabupaten Sumbawa merupakan Kecamatan yang jumlah penduduk wanitanya banyak menjadi tenaga kerja ke luar negeri.

Tabel 1.1 Kecamatan Tertinggi Tingkat TKW di Kabupaten Sumbawa

\begin{tabular}{|c|c|}
\hline KECAMATAN & JUMLAH \\
& TKW \\
\hline Utan & 1.152 \\
\hline Alas Barat & 915 \\
\hline Buer & 744 \\
\hline
\end{tabular}

Sumber : BPS Sumbawa tahun 2009

Tabel 1.1 menunjukan bahwa pada tahun 2009 jumlah TKW Kecamatan Utan mencapai 1.152 membuktikan bahwa Kecamatan Utan merupakan kecamatan tertinggi pengirim TKW di Kabupaten sumbawa, kemudian disusul oleh Alas barat dengan jumlah pengirman TKW sebanyak 915 TKW dan yang ketiga adalah Kecamatan Buer 744 TKW. Dan apabila di rinci perdesa maka desa Jorok Kecamatan Utan adalah salah satu desa dengan jumlah TKW terbanyak di Kecamatan Utan. Ratarata disetiap tahunnya jumlah Tenaga Keja Wanita (TKW) Lebih banyak dari pada tenaga kerja lakilaki. Istilah TKI lebih dominan dengan pekerja lakilaki, seiring berjalannya waktu banyaknya angkatan kerja wanita ke luar negeri membuat istilah TKI lebih di kenal dengan TKW untuk mempertegas bahwa ada TKW di antara TKI (Santri,2010).

Penelitian ini mengkaji alokasi penggunaan dari remitansi TKW luar negeri dan dampak terhadap kesejahteraan TKW ataupun keluarga TKW di derah asal Seperti untuk penggunaan konsumtif atau produktif. Penelitian ini penting untuk dilakukan karena selain melihat dampak kesejahteraan masyarakat karna adanya remitansi yang dikirimkan ke daerah asal bagi TKW dan keluarga juga membantu program pemerintah desmigratif meningkatkan kesejahteraan TKI dari daerah asal sebagai upaya pemerintah melindungi dan meningkatkan kesejahteraan TKI yang berkerja di luar negeri (Cahyu,2017). Dan Juga pengiriman remitansi dengan jumlah yang besar diduga akan mempengaruhi kecenderungan pengalokasian remitan lebih banyak digunakan untuk pendidikan anak untuk mendukung pengembangan sumber daya manusia sejak dini demi masa depan bangsa.

\section{KAJIAN PUSTAKA}

\section{Remittance}

Remittance pada mulanya adalah uang atau barang yang dikirim oleh tenaga kerja daerah asal, sementara tenaga kerja masih berada ditempat tujuan (Wulan,2010). Remittance adalah uang yang dikirim oleh migran atau pelaku migrasi dari daerah tujuan ke daerah asalnya. Pengertian remitan secara umum berasal dari transfer, baik dalam bentuk cash. satu sejenisnya, dari seorang asing kepada sanak keluarga di daerah asalnya (Mantra,1985). Beberapa penelitian sebelumnya mengemukakan remiten tidak hanya berupa uang dan barang saja, pengetahuan, gagasan atau ide-ide dan pengalaman baru yang di peroleh selama bekerja di luar negeri disebut juga sebagai remitan (Mantra,1985).

Tujuan Utama Remittance akan menentukan dampak remitan terhadap pembangunan daerah asal. Berbagai pemikiran dan hasil penelitian telah menemukan keberagaman tujuan remitan ini, menurut Dibyantoro dan Alie (2014) dapat dikelompokkan atas tujuan-tujuan sebagai berikut:

a. Kebutuhan hidup sehari-hari keluarga

Sejumlah besar remitan yang dikirim oleh migran berfungsi untuk menyokong kerabat atau keluarga migran yang ada di daerah asal. Migran mempunyai kewajiban dan tanggung jawab untuk mengirimkan uang atau barang untuk menyokong biaya hidup sehari- hari dari kerabat dan keluarganya, terutama untuk anak-anak dan orang tua. Mantra (1994) pada penelitian di Ghana, Afrika. Di daerah ini, 73 persen dari total remitan yang dikirimkan oleh migran ditujukan untuk memenuhi kebutuhan sehari-hari dari keluarga di daerah asal.

b. Peringatan hari-hari besar yang berhubungan dengan siklus hidup manusia

Di samping mempunyai tanggung jawab terhadap kebutuhan hidup sehari-hari keluarga dan kerabatnya, seorang migran juga berusaha untuk dapat pulang ke daerah asal pada saat diadakan peringatan hari-hari besar yang berhubungan dengan siklus hidup manusia, misalnya kelahiran, perkawinan, dan kematian. Menurut Curson (1983) pada saat itulah, jumlah remitan yang dikirim atau ditinggalkan lebih besar daripada hari-hari biasa.

c. Investasi

Bentuk investasi adalah perbaikan dan pembangunan perumahan, membeli tanah, mendirikan industri kecil, dan lain-lainnya. Kegiatan ini tidak hanya bersifat ekonomi, tetapi juga sebagai sarana sosial dan budaya dalam menjaga kelangsungan hidup di daerah asal, tetapi juga bersifat psikologis, karena erat hubungannya dengan prestise seseorang. Effendi (1993) dalam penelitiannya di tiga desa Jatinom, Klaten menemukan bahwa remitan telah digunakan untuk modal usaha pada usaha-usaha skala kecil seperti pertanian jeruk, peternakan ayam, perdangan dan bengkel sepeda. 


\section{d. Jaminan hari tua}

Migran mempunyai keinginan, jika mereka mempunyai cukup uang atau sudah pensiun, mereka akan kembali ke daerah asal. Hal ini erat kaitannya dengan fungsi investasi, mereka akan membangun rumah atau membeli tanah di daerah asal sebagai simbol kesejahteraan, prestisius, dan kesuksesan di daerah rantau. Lee (1992) mengemukakan bahwa berbagai pengalaman baru yang diperoleh di tempat tujuan, apakah itu keterampilan khusus atau kekayaan, sering dapat menyebabkan orang kembali ke tempat asal dengan posisi yang lebih menguntungkan Selain itu, tidak semua yang bermigrasi bermaksud menetap selama- lamanya di tempat tujuan.

\section{Tenaga Kerja Indonesia (TKI)}

Ada beberapa pendapat mengenai pengertian Tenaga Kerja Indonesia. Menurut Pasal 1 bagian (1) Undang-Undang Nomor 39 Tahun 2004 tentang Penempatan dan Perlindungan Tenaga Kerja Indonesia di Luar Negeri, TKI/TKW adalah setiap warga negara Indonesia yang memenuhi syarat untuk bekerja di luar negeri dalam hubungan kerja untuk jangka waktu tertentu dengan menerima upah. Sedangkan menurut buku pedoman pengawasam perusahaan jasa tenaga kerja Indonesia adalah warga negara Indonesia baik laki-laki maupun perempuan yang melakukan kegiatan di bidang perekonomian, sosial, keilmuan, kesenian, dan olahraga profesional serta mengikuti pelatihan kerja di luar negeri baik di darat, laut maupun udara dalam jangka waktu tertentu berdasarkan perjanjian kerja yaitu suatu perjanjian antara pekerja dan pengusaha secara lisan dan atau tertulis baik untuk waktu tertentu maupun untuk waktu tidak tertentu yang memuat syaratsyarat kerja, hak dan kewajiban para pihak.

Adanya perjanjian kerja ini TKI akan lebih terlindungi apabila nantinya dikemudian hari pihak majikan atau pihak perusahaan tmpat TKI bekerja "wanprestasi"maka TKI dapat menentukan sesuai perjanjian kerja yang telah dibuat sebelumnya. Sementara itu dalam Pasal 1 Kep. Manakertran RI No Kep 104A/Men/2002 tentang penempatan TKI keluar negeri disebutkan bahwa TKI adalah baik laki-laki maupun perempuan yang bekerja di luar negeri dalam jangka waktu tertentu berdasarkan perjanjian kerja melalui prosedur penempatan TKI. Prosedur penempatan TKI ini harus benarbenar diperhatikan oleh calon TKI yang ingin bekerja ke luar negeritetapi tidak melalui prosedur yang benar dan sah maka TKI tersebut nantinya akan menghadapi masalah di negara tempat ia bekerja karena CTKI tersebut dikatakan TKI ilegal karena datang ke negata tujuan tidak melalui prosedur penempatan TKI yang benar. Berdasarkan beberapa pengertian TKI tersebut, maka dapat dikemukakan bahwa TKI adalah setiap warga negara Indonesia yang memenuhi syarat untuk bekerja di luar negeri dalam jangka waktu tertentu berdasarkan perjanjian kerja melalui prosedur penempatan TKI dengan menerima upah.

Indikator Kesejahteraan Sugiharto (2007) menerangkan bahwa untuk melihat tingkat kesejahteraan suatu wilayah ada beberapa indikator yang dapat dijadikan ukuran yaitu :

a.Tingkat pendapatan keluarga

b. Jumlah Pengeluaran rumah tangga

c. Tingkat pendidikan keluarga

d. Tingkat kesehatan keluarga

e. Kondisi perumahan serta fasilitas yang dimiliki dalam rumah tangga

\section{METODE ANALISIS}

Penelitian ini menggunakan metode analisis kualitatif dengan pendekatan deskriftif. Jenis data yang digunakan adalah data primer yang diperoleh melalui wawancara dengan alat bantu kuisioner yang sebelumnya telah dilakukan observasi dan dokumentasi. Lokasi penelitian terletak di desa Jorok Kecamatan Utan Kabupaten Sumbawa. Sempel penelitian ditetapkan dengan cara purposive sampling untuk pakar, ada 15 pakar yang telah diwawancara dan dipilih menurut kriteria yaitu akademisi Fakultas Ekonomi dan Bisnis UTS yaitu dosen S2 yang mengerti tentang kesejahteraan, para akademisi BPS, akedemisi BPKAD dan untuk responden TKW yaitu mantan TKW dan keluarga TKW yang berjumlah 50 orang, ada 29 mantan TKW dan 21 keluarga TKW yang bertanggung jawab atas keuangan TKW saat TKW berada dinegara tujuan. Responden telah diwawancara secara convenience sampling atau dengan cara pengambilan sampel berdasarkan pada ketersediaan elemen atau responden dan kemudahan untuk mendapatkannya. sampel dipilih karena sampel tersebut ada pada tempat dan waktu yang tepat. Alat analisis yang digunakan adalah kualitatif dengan langka-langka :

a. Reduksi Data

Penyederhanaan data kasar yang muncul dari catatan-catatan lapangan, sehingga data tersebut memberi gambaran yang lebih jelas tentang hasil observasi, wawancara, dan dokumentasi (Huberman,2009).

b. Penyajian Data

Sekumpulan informasi tersusun memberi kemungkinan adanya penarikan kesimpulan dan pengambilan tindakan dalam bentu tabel, bagan, tabel, grafik dll sehingga makin mudah dipahami (Huberman,2009).

c. Simpulan dan vrefikasi

Simpulan dan verivikasi merupakan membuatan kesimpulan berdasarkan data yang telah diproses melalui reduksi dan penyajian data (Huberman,2009). 
kedua adalah dengan analisis hirarki proses yaitu penyusunan kerangka untuk mendukung pengambilan keputusan dengan memecahkan persoalan tersebut ke dalam bagian-bagiannya yaitu

\section{Dekomposisi Masalah}

Hierarki I:Tujuan yang ingin dicapai agar dapat menjawab dampak pengunaan remittance terhadap tingkat kesejahteraan tenaga kerja.

Hierarki II : Menentukan kriteria yang di gunakan yang sebelumnya telah dijawab oleh rumusan masalah pertama. di gunakan.

Hierarki III: Menentukan alternatif yang

Menentukan alternatif terpilih dari hasil penyelsaian hierarki I, II, III.

2. Penilaian Dan Pembobotan

Pada jenis kuisioner ini, kecendrungan pembobotan dilingkari atau disilang berdasarkan bobotnya, jika sisi kiri lebih penting dari sisi kanan maka angka yang dilingkari adalah 9-1 pada ruas kiri dan sebaiknya (Wardiyansa,2013).

3. Menyusun Matriks/ Uji Konsisitensi

Menyatuhkan pendapat dari kuisioner yang diisi oleh responden tersebut akan di satukan pendapatnya dengan mengunakan persamaan ratarata geometri. $\mathrm{GM}=\sqrt{ }(\mathrm{n} \&(\mathrm{X} 1)(\mathrm{X} 2)(\mathrm{X} 3) \ldots(\mathrm{Xn})$

Dimana: $\mathrm{GM}=$ Geometri mean
$\mathrm{X} 1=$ Pakar 1
$\mathrm{X} 2=$ Pakar 2
$\mathrm{X} 3=$ Pakar 3
$\mathrm{Xn}=$ Pakar $\mathrm{n}$

a. Rubah angka dalam bentuk Matriks dari nilai Fraksi ke dalam bentuk desimal.

b. Lakukan normalisasi pada semua matriks desimal alternatif yang telah di buat.

c. Menentukan nilai Eigen Vektor (EV), dengan merata-ratakan nilai baris pada tiap elmen. Perhitungan dilakukan untuk masing-masing elemen pada tiap matriks hasil normalisasi.

d. Menentukan nilai eigen terbesar untuk tiap-tiap matriks, eigen terbesar di peroleh dengan mengalihkan total matriks sebelum normaliasi dengan nilai eigen vektor utama dengan rumus $: \Lambda$ maksimun $=\left(\sum\right.$ 『GM_ $\left.(11 \mathrm{n} 1) \times \mathrm{X} 1\right)+\ldots+\left(\sum \mathrm{GM}\right.$ $\left.\rrbracket \_(1 n-n i) \times X n\right)$

e. Menentukan nilai indeks konsistensi (CI) Sesuai dengan persamaan $\mathrm{CI}=(\lambda$ maksimum $-\mathrm{n}) /(\mathrm{n}-1)$ $\mathrm{CI}=(4.148-4) /(4-1)=0.049$

4. Sintesis ( Iterasi Matriks)

a. Langka berikutnya adalah mengelolah bentuk matriks 2 dengan jalan yang sama dengan matriks 1( iterasi II) Kemudian jumlahkan kembali hasil perkalian silang matriks berdasarkan baris. Selanjutnya hitung selisih antar vektor matriks 1 dan 2 dalam iterasi II. b. Langka ini diulang, hingga nilai selisi antara iterasi tidak mengalami perubahan atau sama $(=0)$, jika iterasi telah memperoleh nilai selisi hasil normalisasi yang bernilai 0 artinya proses iterasi tidak perlu dilanjutkan

\section{Penarikan Kesimpulan}

Analisis Data Kualitatif Responden

Ada 50 Responden yang telah di wawancarai berdasarkan kategori, ada 21 Keluarga TKW dan 29 Mantan TKW, kemudian berdasarkan status Perkawinan ada 16 TKW yang Belum Kawin dan 34 yang sudah Kawin. Penanggung Jawab Keuangan ada 32 dari Anggota Keluarga Lainnya dan 18 dari Suami TKW khususnya yang sudah menikah. Kemudian berdasarkan tempat tinggal ada 31 TKW yang sudah memiliki rumah dan 19 TKW masih tinggal bersama orang tua.

\section{HASIL DAN PEMBAHASAN}

\section{Alokasi Penggunaan Remittance TKW Desa} Jorok Kecamatan Utan

Alokasi penggunaan remittance di Desa Jorok Kecamatan Utan beradarkan hasil penelitian yaitu ada dua kategori penggunaan yaitu penggunaan konsumtif dan penggunaan prooduktif. Pada penggunaan konsumtif TKW didesa jorok Kecamatan Utan mengalokasikan dana remittance mereka untuk memenuhi kebutuhan sehari-hari, merenovasi atau membangun rumah, membayar hutang dan membeli kendaraan pribadi. Sedangkan untuk penggunaan produktif TKW mengalokasikan dana Remittance mereka untuk pendidikan, membeli tanah, membeli hewan ternak dan usaha, pada penelitian ini dari jumlah pendapatan rata-rata TKW dan dan jumlah remittance TKW dibagi dalam empat kateori yaitu menurut status perkawinan, penanggung jawab keuangan TKW selama berada diluar negeri, tempat tinggal TKW dan status responden yang telah diwawancara. 
Tabel 1.2 Jumlah Rata-Rata Pendapatan dan Rata-Rata Remittance TKW Perkategori

\begin{tabular}{|c|c|c|c|c|}
\hline No & Status Perkawinan & Jumlah Orang & Pendapatan Rata-Rata P & Remittance Rata-Rata \\
\hline 1 & Kawin & 34 & Rp 4,361,764.71 & Rp 2,915,441.03 \\
\hline 2 & Belum Kawin & 16 & Rp 5,556,250.00 & Rp 3,241,666.63 \\
\hline No Penanggung Jawab Keuangan & Jumlah Orang & Pendapatan Rata-Rata P & Remittance Rata-Rata \\
\hline 1 & Suami & 18 & Rp 4,484,375.00 & Rp 2,859,895.75 \\
\hline 2 & Keluarga Lainnya & 32 & Rp 5,205,555.56 & Rp 3,304,166.50 \\
\hline No & Tempat Tinggal & Jumlah orang & Pendapatan Rata-Rata P & Remittance Rata-Rata \\
\hline 1 & Rumah Sendiri & 31 & Rp 4,332,258.06 & Rp 2,864,247.19 \\
\hline 2 & Rumah Orang Tua & 19 & Rp 5,415,789.47 & Rp 3,273,684.11 \\
\hline No & Status Responden & Jumlah Orang & Pendapatan Rata-Rata P & Remittance Rata-Rata \\
\hline 1 & Keluarga TKW & 21 & Rp 5,804,761.90 & Rp 3,531,349.10 \\
\hline 2 & Mantan TKW & 29 & Rp 3,975,862.07 & Rp 2,649,425.17 \\
\hline
\end{tabular}

Sumber: Data Primer di Olah 2019.

Status perkawinan TKW merupakan salah satu alasan TKW memutuskan untuk berkerja di luar negeri. Hasil penelitian tabel 1.1 menunjukan bahwa ada 34 TKW yang sudah kawin, dari $100 \%$ pendapatan rata-rata TKW tersebut, sebesar $47 \%$ yang dikirimkan ke dalam negeri sebagai remittance TKW, sedangkan sisanya 53\% disimpan untuk keperluan lainnya atau digunakan sebagai pemenuhan kebutuhan TKW selama berada di negara tujuan. Begitu pula dengan 16 TKW yang belum kawin, dari $100 \%$ pendapatan mereka di luar negeri, sebesar $53 \% \%$ yang dikirimkan ke daerah asal sebagai remittance dan sisanya $47 \%$ dari 16 TKW tersebut digunakan untuk pemenuhan kebutuhan di negara tujuan atau disimpan untuk dikirim lagi sesuai keadaan kebutuhan di daerah asal. Tabel 1.1 juga menunjukan bahwa jumlah remittance TKW yang belum menikah lebih besar dengan remittance yang sudah menikah. Salah satu alasan terbesar TKW ke luar negeri adalah karna ingin meringankan beban keluarga di daerah asal khususnya orang tua bagi yang belum menikah, fakta lapangan menunjukaan bahwa pengiriman remittance lebih banyak dilakukan oleh TKW yang belum menikah karna besarnya keinginan untuk berinvetasi dalam bentuk tanah, bangunan ataupun tabungan menjadi salah satu jaminan untuk bertahan hidup jika suatu saat TKW kembali ke daerah asal, saat diwawancarai rata-rata dari TKW yang sudah menikah adalah mantan TKW, adanya peningkatan jumlah inflasi menbuat pendapatan mantan TKW terhitung lebih rendah jika dibandingkan dengan jumlah pendapatan TKW yang saat ini berada diluar negeri. Semakin tinggi pendapatan TKW dinegara tujuan maka akan berpengaruh kepada jumlah pengiriman remittance TKW yang akan cenderung meninggkat ( Ma'arif,2017)

Penanggung jawab keuangan TKW selama berada diluar negeri mempengaruhi pengalokasikan dana remittance, kepercayaan TKW atas penanggung jawab keuangan, status pernikahan dan minimnya pengetahuan dalam megelolah keuangan menjadi faktor mengapa TKW memberi tanggung jawab seseorang yang dapat dipercaya untuk memegang keuangan TKW selama berada diluar negeri. Tabel 1.1 menunjukan bahwa 18 dari 50 TKW memepercayakan keuangannya dikelolah oleh suami dan 32 TKW mempercayakan keuangannya kepada keluarga lainnya seperti ibu,bapak,paman, nenek, bibi dan ipar. Tabel 4.2.2 juga menunjukan bahwa dari $100 \%$ pendapatan ratarata TKW yang dikelolah oleh suami ada $56 \%$ yang dikirimkan sebagai remittance dan $44 \%$ disimpan, juga untuk kebutuhan pripadi TKW, begitupun dengan TKW yang memberi tanggung jawab kepada keluarga lain, ada $46 \%$ dana remittance yang dikirimkan ke daerah asal dan 54\% disimpan untuk ditabung demi untuk pemenuhan kebutuhan jangka panjang TKW . Hasil penelitian dari tabel tersebut menunjukan bahwa pengiriman remittance TKW lebih banyak nominal atau jumlah dana remittannce yang dikirimkan kepada suami TKW dari pada keluarga lainnya dikarnakan rata-rata dari TKW sudah mempunyai keluarga sendiri dan merasa lebih aman jika suami sendiri yang bertanggung jawab atas dana remittance, ada juga dari TKW yang sudah berkeluarga tetapi lebih mempercayakan keuangannya dengan keluarga lainnya selain suami seperti ibu, bapak, paman, bibi, nenek dan juga ipar. Menurut hasil penelitian lapangan mengapa ada TKW yang sudah berumah tangga tetapi lebih mempercayakan keuangan ke keluarga lainnya, ini dikarnakan kebanyakan dari suami TKW tidak mengerti mengelolah keuangan, tetapi ada juga dengan alasan sudah berpisah dengan suami ataupun suami sudah meninggal dunia. Sedangkan faktor terbesar mengapa TKW lebih banyak melakukan remittance kepada suami, dikarnakan TKW yang diwawancara pada penelitian ini lebih banyak TKW yang sudah berumah tangga. 
Tabel 1.1 mununjukan bahwa dari 50 TKW ada 31 TKW yang sudah memiliki rumah sendiri dan ada 19 TKW yang masih tinggal dirumah orang tua, berdasarkan jumlah pendapatan rata-rata TKW pada tabel diatas mununjukan bahwa dari $100 \%$ pendapatan rata-rata TKW kategori kepemilikan rumah atau tempat tinggal, TKW yang tingal dirumah sendiri melakukan remittance sebesar $47 \%$ dan sisanya $53 \%$ disimpan untuk pribadi dan digunakan untuk kebutuhan TKW dinegara tujuan, sedangkan untuk TKW yang masih tinggal dirumah orang tua melakukan remittance sebesar 53\% dan sisanya $47 \%$ untuk disimpan dan digunakan TKW dinegara tujuan. Kepemilikan rumah atau tempat tinggal TKW juga mempengaruhi jumlah remittance TKW, khususnya bagi yang belum memiliki rumah sendiri. Hasil penelitian pada tabel 1.1 menunjukan bahwa pengiriman remittance lebih banyak dilakukan oleh TKW yang masih tinggal dirumah orang tua. Ingin membangun rumah dan dapat tinggal dirumah layak huni baik yang sudah berkeluarga ataupun belum berkeluarga menjadi salah satu alasan mengapa TKW yang masih tinggal dirumah orang tua lebih banyak melakukan remittance dari pada TKW yang sudah memiliki dirumah sendiri.

Tabel 1.1 menunjukan bahwa ada 21 keluarga TKW yang telah diwawancarai dan 29 mantan TKW. Dari $100 \%$ pendapatan rata-rata TKW yang masih berada diluar negeri ada $57 \%$ yang dikirimkan sebagai dana remittance dan $43 \%$ disimpan atau digunakan untuk kebutuhan hidup TKW selama masih berada di negara tujuan dan dari $100 \%$ pendapatan rata-rata mantan TKW sebanyak $43 \%$ yang pernah dikirimkan sebagai remittance TKW ketika berada di negara tujuan dan TKW mengaku ada $57 \%$ untuk disimpan dan digunakan untuk kebutuhan hidup selama TKW berada dinegara tujuan. Tabel 1.1 juga menunjukan bahwa pengiriman remittance lebih banyak dilakukan oleh keluarga TKW, fakta lapangan menunjukaan bahwa pengiriman remittance lebih banyak dilakukan oleh TKW yang masih berada diluar negeri, usia mudah membuat mereka berkeinginan untuk berinvetasi dalam bentuk tanah, bangunan ataupun tabungan menjadi salah satu jaminan untuk bertahan hidup jika suatu saat TKW kembali ke daerah asal ataupun saat TKW ingin menikah, adanya peningkatan jumlah inflasi menbuat pendapatan mantan TKW terhitung lebih rendah jika dibandingkan dengan jumlah pendapatan TKW yang saat ini berada diluar negeri. Semakin tinggi pendapatan TKW dinegara tujuan maka akan berpengaruh kepada jumlah pengiriman remittance TKW yang akan cenderung meninggkat ( Ma'arif,2017).

\footnotetext{
Penggunaan Dana Remittance Konsumtif dan Produktif Berdasarkan Beradasarkan Status Perkawinan
}

Hasil penelitian Penggunaan konsumtif dana remittance berdasarkan status perkawinan di Desa Jorok Kecamatan Utan menunjukan bahwa penggunaan remittance TKW yang sudah kawin untuk penggunaan kebutuhan sehari-hari yaitu sebesar 59\% dari penggunaan konsumtif lainnya sedangkan TKW yang belum kawin menggunakan hanya $40 \%$ penggunaan dana remittance dari semua pengunaan konsumtif lainnya. Untuk penggunaan yang kedua yaitu renovasi rumah, pada penggunaan ini TKW yang sudah kawin lebih sedikit menggunakan dana remittance dan hanya $29 \%$ dari penggunaan konsumtif lainya, sedangkan untuk TKW yang belum kawin lebih besar yaitu sebesar $53 \%$ dari penggunaan lainnya, Kemudian yang ketiga yaitu bayar hutang, sedikitnya 2\% yang digunakan pada penggunaan ini oleh TKW yang sudah menikah dan tidak jauh berbeda dengan TKW yang belum menikah, hanya $4 \%$ yang digunakan pada penggunaan bayar hutang. Yang terakhir yaitu kendaraan, ada $10 \%$ dana remittance yang digunakan untuk membeli kendaraan oleh TKW yang sudah kawin dan 3\% penggunaan dana remittance oleh TKW yang belum kawin.

Penggunaan produktif dana remittance berdasarkan status perkawinan di Desa Jorok Kecamatan Utan menunjukan bahwa penggunaan dana remittance TKW yang sudah kawin untuk penggunaan produktif pendidikan anak yaitu sebesar $73 \%$ dari penggunaan produktif lainnya, sedangkan TKW yang belum kawin menggunakan dana remittance hanya sebesar $22 \%$ dari penggunaan lainnya. Yang kedua yaitu beli tanah, hasil penelitian menunjukan rata-rata TKW yang sudah menikah hanya $22 \%$ menggunakan dana remittance untuk membeli tanah sebagai salah satu investasi masa depan TKW, karna sebagian besar telah digunakan untuk pendidikan anak, jika di bandingkan dengan TKW yang belum kawin maka penggunaan dana remittance lebih besar yaitu $62 \%$ dari penggunaan lainnya.Yang ke tiga yaitu membeli hewan ternak, tidak banyak TKW yang sudah kawin ataupun belum kawin mengalokasikan penggunaan remittance pada pembelian hewan ternak karna dianggap terlalu merepotkan dan hasilnya sedikit, kadang juga tak menentu, jika membeli membeli hewan ternak TKW yang sudah kawin atapun belum kawin mempunyai alasan yang sama yaitu sebagai investasi masa depan yang jumlahnya akan bertambah jika dikembangbiakkan secara baik. Jika dibandingkan dengan penggunaan lainnya Hanya 4\% penggunaan oleh TKW yang sudah kawin dan hanya $1 \%$ penggunaan dana remittance dari penggunaan produktif lainnya oleh TKW yang belum kawin.yang keempat yaitu usaha, sama halnya dengan penggunaan hewan ternak, penggunaan usaha untuk TKW yang belum kawin ataupun sudah kawin tidak begitu diminati, Cuma 
$1 \%$ penggunaan dana remittance oleh TKW yang sudah kawin dan 5\% oleh TKW yang belum kawin.

\section{Penggunaan Dana Remittance Konsumtif dan Produktif Berdasarkan Beradasarkan penanggung jawab keuangan \\ Hasil penelitian penggunaan konsumtif} dana remittance berdasarkan penanggung jawab keuangan di Desa Jorok Kecamatan Utan menunjukan bahwa penggunaan remittance TKW yang dikelolah oleh suami untuk penggunaan kebutuhan sehari-hari yaitu sebesar $52 \%$ dari penggunaan konsumtif lainnya sedangkan untuk penanggung jawab keuangan oleh keluarga lainnya lebih tinggi sebesar $55 \%$ penggunaan dana remittance dari semua penggunaan konsumtif lainnya. Yang kedua yaitu penggunaan dana remittance untuk merenovasi atau membangun rumah, pada penggunaan ini penanggung jawab keuangan juga dapat dikelolah oleh suami TKW walaupun tidak dalam jumlah banyak, sebesar $32 \%$ penggunaan dana remittance oleh suami TKW dari penggunaan remittance lainnya, sedangakan untuk penggunaan dana remittance yang dikelolah oleh keluarga TKW lebih tinggi sebesar 38\% dari penggunaan konsumtif lainnya. Yang ketiga yaitu penggunaan konsumtif untuk membayar hutang, tidak banyak penggunaan dana remittance yang digunakan pada penggunaan konsumtif ini, pada penggunaan ini TKW lebih banyak memberi tanggung jawab untuk keluarga lainnya selain suami bagi yang sudah berumah tangga, sedikitnya $4 \%$ pengunaan dana remittance pada penggunaan ini. Keempat yaitu penggunaan dana remittance untuk kendaraan, dalam penggunaan ini TKW lebih banyak memberi tanggung jawab kepada suami sendiri karena kebanyakan dari TKW sudah memiliki anak dan butuh transportasi jika ingin berpergian kesekolah ataupun ketempat lainnya. sebesar 16\% yang digunakan pada penggunaan ini dari penggunaan-penggunaan lainnya.

Hasil penelitian pada penggunaan produktif dana remittance berdasarkan penanggung jawab keuangan di Desa Jorok Kecamatan Utan menunjukan bahwa sebesar $76 \%$ penggunaan dana remittance pendidikan yang dikelolah oleh suami TKW dan 53\% penggunaan. Penggunaan kedua yaitu beli tanah, TKW yang memberi tanggung jawab kepada suami sebesar $21 \%$ penggunaan dana remittance digunakan untuk membeli tanah dibandingkan dengan penggunaan lainnya danyang dikelolah oleh keluarga lain TKW sebesar $37 \%$ penggunaan dana remittance dari penggunaan konsumtif lainnya. Penggunaan ketiga yaitu hewan ternak, tidak banyak TKW yang mengalokasikan dana remittance untuk membeli hewan ternak, ada $3 \%$ penggunaan remittance yang dikelolah oleh suami dan ada $8 \%$ penggunaan remittance yang dikelolah oleh keluarga lainnya, yang kempat yaitu usaha, tidak banyak bahkan sangat sedikit TKW yang mengalokasikan dana remittance untuk usaha, hanya $2 \%$ yang dikelolah oleh keluarga lainnya dari penggunaan produktif lainnya.

\section{Penggunaan Dana Remittance Konsumtif dan Produktif Berdasarkan Beradasarkan Tempat Tinggal TKW.}

Hasil peneliti penggunaan konsumtif dana remittance berdasarkan kepemilikan rumah atau tempat tinggaldi Desa Jorok Kecamatan Utan menunjukan bahwa pada pengunaan konsumtif kebutuhan sehari-hari lebih besar digunakan oleh TKW yang sudah memiliki rumah sendiri, sebesar $55 \%$ dana remittance yang digunakan pada penggunaan ini dari tiga penggunaan lainnya, sedangkan untuk TKW yang masih tinggal bersama orang tua penggunaannya lebih kecil dari penggunaan yang sudah memiliki rumah sendiri yaitu sebesar $45 \%$ dari penggunaan lainya. Kemudian untuk penggunaan kedua yaitu merenovasi rumah, pada pengunaan ini TKW yang masih tinggal dirumah orang tua lebih tinggi penggunaan dana remittance dibandingkan TKW yang sudah memiliki rumah sendiri, sebesar $49 \%$ dana remittance yang digunakan oleh TKW yang masih tinggal dirumah orang tua, keinginan untuk memiliki rumah membuat TKW lebih banyak mengunakan dana remittance untuk merenovasi atau membangun rumah dibandingkan penggunaan konsumtif lainnya agar mereka memiliki rumah idaman yang layak huni. Sedangkan untuk TKW yang sudah memiliki rumah lebih sedikit, sebesar 45\% dibandingkan dengan TKW yang belum memiliki rumah dan jika dibandingkan dengan penggunaan lainnya, sudah memiliki rumah membuat TKW lebih berfokus menggunakan dana remittance untuk penggunaan lainnya. Yang ke tiga yaitu penggunaan dana untuk membayar hutang, kesulitan keuangan TKW sebelum berangkat ke luar negeri menjadi penyebab timbulnya hutang, pada penggunaan ini TKW yang sudah memiliki rumah sendiri cenderung lebih sedikit memiliki hutang dibandingkan TKW yang masih tinggal dirumah orang tua, sedikinya hanya $2 \%$ hutang TKW yang sudah memiliki rumah dan 3\% hutang TKW yang masih tinggal berasa orang tua, jika di bandingkan dengan penggunaan lainnya penggunaan ini lebih sedikit dan jarang digunakan. Yang terakhir yaitu kendaraan, sebesar $11 \%$ penggunaan dana remittance digunakan oleh TKW yang sudah memiliki rumah dibandingkan dengan penggunaan lain. Dan lebih kecil penggunaan remittance oleh TKW yang masih tinggal bersama orang tua, sedikitnya hanya $3 \%$ dari penggunaan lainnya. Hal ini dikarnakan tidak ada penggunaan yang lebih besar yang harus digunakan oleh TKW yang sudah memiliki rumah sendiri,tidak seperti TKW yang 
masih tinggal bersama orang tua dan ini ngin membangun atau merenovasi rumah.

Hasil penelitian pada gambar Penggunaan produktif dana remittance berdasarkan kepemilikan rumah atau tempat tinggal di Desa Jorok Kecamatan Utan Menunjukan bahwa pada penggunaan produktif pendidikan lebih banyak digunakan oleh TKW yang sudah memiliki rumah sendiri, sebesar $72 \%$ dana remittance yang digunakan pada penggunaan ini dari tiga penggunaan lainnya, sedangkan untuk TKW yang masih tinggal bersama orang tua penggunaannya lebih kecil dari penggunaan yang sudah memiliki rumah sendiri yaitu $41 \%$ dari penggunaan lainya. Penggunaan yang kedua yaitu beli tanah, TKW yang sudah memiliki rumah cenderung sedikit menggunakan dana remittance untuk memebeli tanah, hanya $22 \%$ dana remittance yang digunakan dari penggunaan lainnya. berbeda dengan TKW yang masih tinggal bersama orang tua, rata-rata dari mereka belum menikah dan ingin mempunyai rumah sendiri ketika pulang ke daerah asal, sebelum membangun rumah TKW terlebih dahulu membeli tanah yang lokasinya cocok untuk dibangun rumah yang mereka inginkan, sebesar $49 \%$ penggunaan dana remittance dari penggunaan lainnya. Yang ke tiga yaitu hewan ternak, sama dengan kategori-kategori lainnya, penggunaan remittance untuk pembelian hewan ternak tidak terlalu banyak diminati karena dianggap terlalu merepotkan dalam merawatnya dan hasilnya tidak menentu, hanya $5 \%$ penggunaan dana remittance hewan ternak oleh TKW yang sudah memiliki rumah dan $7 \%$ oleh TKW yang masih tinggal bersama orang tua. Yang keempat adalah usaha sama halnya dengan pengalokasian untuk hewan ternak, sangat sedikit yang meminati penggunaan ini, pengetahuan yang terbatas dan modal yang dialokasikan kepenggunaan lain membuat TKW tidak begitu banyak menggunakan penggunaan ini, hanya $1 \%$ dana remittance yang digunakan oleh TKW yang sudah memiliki rumah dan 3\% yang digunakan oleh TKW yang masih tinggal bersama orang tua.

\section{Penggunaan Dana Remittance Konsumtif dan Produktif Berdasarkan Beradasarkan Status Responden.}

Hasil penelitian pada penggunaan konsumtif dana Remittance berdasarkan status responden di Desa Jorok Kecamatan Utan menunjukan bahwa pada penggunaan dana remittance lebih banyak digunakan oleh mantan TKW, sebesar $56 \%$ penggunaan dana remittance digunakan pada penggunaan ini, sedangkan ada $43 \%$ yang digunakan oleh keluarga TKW dibandingkan penggunaan lainnya, ini disebabkan karna rata-rata dari mantan TKW sudah berkeluarga sehingga kebutuhan hidup sehari-hari meningkat dan tidak lagi untuk kepentingan diri sendiri melainkan ada anak dan suami yang juga harus dicukupi. Sedangkan keluarga TKW atau TKW yang masih berada diluar negeri lebih sedikit menggunakan dana remittance pada penggunaan kebutuhan sehari-hari karna dana remittance kebanyakan digunakan untuk disimpan dan juga berinvestasi, seperti membeli tanah, hewan ternak dll sebelum TKW kembali ke daerah asal. Yang kedua yaitu renovasi rumah, pada penggunaan ini keluarga TKW atau TKW yang masih berada diluar negeri lebih banyak menggunakan dana remittance untuk merenovasi rumah, sebesar $51 \%$ penggunaan dana remittance dibandingkan penggunaan lainnya, dan mantan TKW hanya menggunakan $32 \%$ dana remittance, penggunaan lebih sedikit dibandingkan TKW yang masih berada diluar negeri, hal ini disebabkan karna kebanyakan mantan TKW sudah menikah dan memiliki anak, mereka cenderung berfokus pada pendidikan anak kedepannya dan kelangsungan hidup dimasa yang akan datang, sedangkan keluarga TKW lebih mementingkan membangun atau merenovasi rumah dan juga berinvestasi seperti membeli tanah, menabung dll. Yang ketiga yaitu bayar hutang, pada penggunaan ini baik TKW ataupun mantan TKW tidak banyak mengalokasikan remittance mereka untuk membayar hutang, jika dibandingkan jumlah hutang mantan TKW sedikit lebih besar yaitu 3\% dari penggunaan lainnya dan hanya $1 \%$ penggunaan oleh keluarga TKW atau TKW yang masih berada di luar negeri. Penggunaan trakhir yaitu kendaraan, pada penggunaan ini dana remittancelebih besar adalah 9\% dari penggunaan lainnya oleh mantan TKW dan sedikitnya $5 \%$ penggunaan remittance oleh keluarga TKW.

Hasil penelitian pada penggunaan produktif dana remittance berdasarkan status respondendi Desa Jorok Kecamatan Utan menunjukan bahwa pada penggunaan dana remittance lebih banyak digunakan oleh mantan TKW, sebesar $73 \%$ penggunaan dana remittance digunakan pada penggunaan ini, sedangkan ada $35 \%$ yang digunakan oleh keluarga TKW dibandingkan penggunaan lainnya, ini disebabkan karna rata-rata dari mantan TKW sudah berkeluarga juga memiliki anak dan menyekolahkan anak adalah tanggung jawab besar bagi mantan TKW, walaupun keluarga TKW atau TKW yang masih diluar negeri rata-rata belum menikah mereka juga menggunakan penggunaannya tetapi hanya sedikit karna rata-rata hanya membantu orang tua membiayai pendidikan adik atau keluarga lainnya. Yang kedua yaitu penggunaan dana remittance untuk membeli tanah. Penggunaan remittance keluarga TKW atau TKW yang masih diluar negeri terbilang cukup tinggi yaitu 52\%, pembelian tanah oleh keluarga TKW digunakan untuk berinvestasi karena mereka paham harga tanah setiap tahun akan meningkat, untuk mantan TKW hanya $22 \%$ dana remittance yang 
dialokasikan untuk pembelian tanah dari penggunaan lainnya, rata-rata mantan TKW sudah menikah dan memiliki anak membuat mantan TKW lebih berfokus pada pendidikan anak. Yang ketiga yaitu hewan ternak, keluarga TKW mengalokasikan 9\% dana remittance dari penggunaan lainnya untuk membeli hewan ternak, sedangkan mantan TKW hanya menggunakan dana remittance sediknya $4 \%$ dari penggunaan lainnya. Kemudian yang keempat yaitu penggunaan dana remittance pada usaha, sama seperti hewan ternak tidak banyak yang meminati penggunaan usaha, hanya sekitar $4 \%$ dana remittance yang dialokasikan untuk usaha oleh keluarga TKW dan sedikitnya hanya 1\% yang digunakan untuk usaha oleh mantan TKW.

\section{Alokasi Yang Memberi Dampak Paling Baik Terhadap Tingkat Kesejahteran Masyarakat}
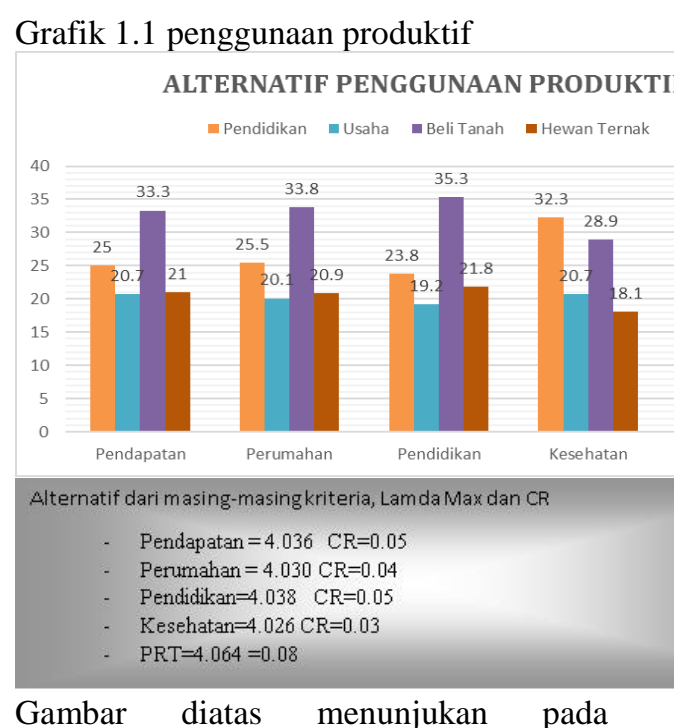

penggunaan produktif kriteria pendapatan menunjukan bahwa menurut hasil pembobotan 50 reponden alternatif yang paling mempengaruhi dalam memperoleh pendapatan pada penggunaan produktif adalah beli tanah. TKW lebih memprioritaskan membeli tanah dibandingkan dengan penggunaan produktif lainnya. Kemudian alokasi penggunaan terpenting kedua menurut mereka adalah pendidikan, disusul oleh hewan ternak dan yang trakhir adalah usaha. Setelah itu didapat hasil dari lamda maksimum dan CR menunjukan hasil adalah 0.05yang berarti nilai konsisten atau hasil dapat diterima.

Diagram batang pada penggunaan produktif kriteria perumahan menunjukan bahwa menurut hasil pembobotan 50 reponden alternatif yang paling mempengaruhi dalam membangun rumah pada penggunaan produktif adalah beli tanah. TKW lebih memprioritaskan membeli tanah dibandingkan dengan penggunaan produktif lainnya. Kemudian alokasi penggunaan terpenting kedua menurut mereka adalah pendidikan, disusul oleh hewan ternak dan yang trakhir adalah usaha. Setelah itu didapat hasil dari lamda maksimum dan CR menunjukan hasil adalah 0.04 yang berarti nilai konsisten atau hasil dapat diterima.

Diagram batang pada penggunaan produktif kriteria pendidikan menunjukan bahwa menurut hasil pembobotan 50 reponden alternatif yang paling mempengaruhi dalam mengenyam pendidikan pada penggunaan produktif adalah beli tanah. TKW lebih memprioritaskan membeli tanah dibandingkan dengan penggunaan produktif lainnya. Kemudian alokasi penggunaan terpenting kedua menurut mereka adalah pendidikan, disusul oleh hewan ternak dan yang trakhir adalah usaha. Setelah itu didapat hasil dari lamda maksimum dan CR menunjukan hasil adalah 0.05 yang berarti nilai konsisten atau hasil dapat diterima.

Diagram batang pada penggunaan produktif kriteria kesehatan, menunjukan bahwa dari hasil pembobotan 50 reponden alternatif yang paling mempengaruh untuk menjaga kesehatan pada penggunaan produktif adalah pendidikan. TKW lebih memprioritaskan pendidikan dibandingkan dengan penggunaan produktif lainnya. Kemudian alokasi penggunaan terpenting kedua menurut mereka adalah beli tanah, disusul oleh usaha dan yang trakhir adalah hewan ternak. Setelah itu didapat hasil dari lamda maksimum dan CR menunjukan hasil adalah 0.03yang berarti nilai konsisten atau hasil dapat diterima.

Diagram batang pada penggunaan produktif kriteria pengeluaran rumah tangga menunjukan bahwa hasil dari pembobotan 50 reponden alternatif yangpaling mempengaruhi dalam pengeluaran rumah tangga, pada penggunaan produktif adalah pendidikan. TKW lebih memprioritaskan pendidikan dibandingkan dengan penggunaan produktif lainnya. Kemudian alokasi penggunaan terpenting kedua menurut mereka adalah beli tanah, disusul oleh hewan ternak dan yang trakhir adalah usaha.

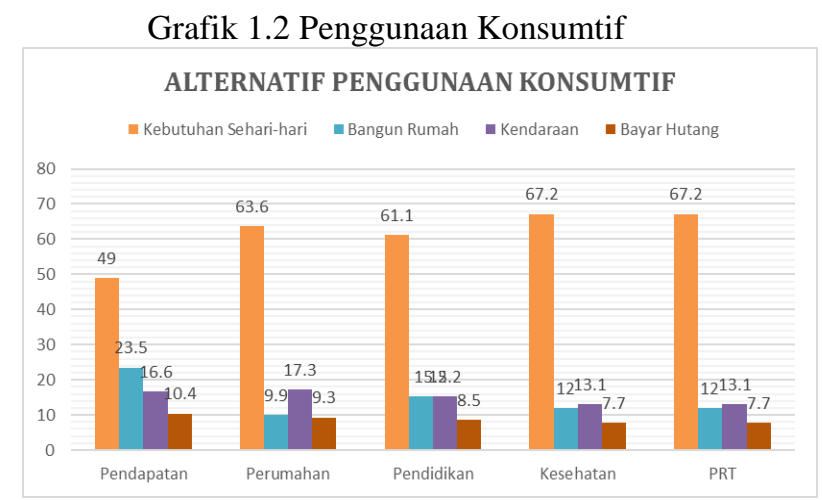




\section{Alternatif dari masing-masingkriteria, Lamda Max dan CF \\ Pendapatan $=4.044 \mathrm{CR}=0.06$ \\ Perumahan $=4.058 \mathrm{CR}=0.08$ \\ Pendidikan=4.039 $\quad \mathrm{CR}=0.05$ \\ Kesehatan $=4.049 \mathrm{CR}=0.06$ \\ $\mathrm{PRT}=4.049=0.06$}

Gambar menunjukan bahwa pada penggunaan konsumtif kriteria pendapatan, berdasarkan hasil pembobotan 50 reponden alternatif yang paling mempengaruhi dalam memperoleh pendapatan pada penggunaan konsumtif adalah kebutuhan sehari-hari. TKW lebih memprioritaskan kebutuhan sehari-hari dibandingkan dengan penggunaan konsumtif lainnya. Kemudian alokasi penggunaan terpenting kedua menurut mereka adalah bangun rumah, disusul oleh kendaraan dan yang trakhir adalah bayar utang. Setelah itu didapat hasil dari lamda maksimum dan CR menunjukan hasil adalah 0.06 yang berarti nilai konsisten atau hasil dapat diterima.

Diagram batang pada penggunaan konsumtif kriteria perumahan menunjukan, menurut hasil pembobotan 50 reponden alternatif yang paling mempengaruhi dalam membangun rumah pada penggunaan konsumtif adalah kendaraan.TKW lebih memprioritaskan kendaraan dibandingkan dengan penggunaan konsumtif lainnya. Kemudian alokasi penggunaan terpenting kedua menurut mereka adalah kebutuhan seharihari, disusul oleh bangun rumah dan yang trakhir adalah bayar utang. Setelah itu didapat hasil dari lamda maksimum dan CR menunjukan hasil adalah 0.08 yang berarti nilai konsisten atau hasil dapat diterima. Diagram batang pada penggunaan konsumtif kriteria pendidikan menunjukan bahwa, menurut hasil pembobotan 50 reponden alternatif yang paling mempengaruhi dalam mengenyam pendidikan pada penggunaan konsumtif adalah kebutuhan sehari-hari.TKW lebih memprioritaskan kebutuhan sehari-hari dibandingkan dengan penggunaan konsumtif lainnya. Kemudian alokasi penggunaan terpenting kedua menurut mereka adalah kendaraan, disusul oleh bangun rumah dan yang trakhir adalah bayar utang. Setelah itu didapat hasil dari lamda maksimum dan CR menunjukan hasil adalah 0.05 yang berarti nilai konsisten atau hasil dapat diterima.

Diagram Batang pada penggunaan konsumtif kriteria pendidikan menunjukan bahwa, menurut hasil pembobotan 50 reponden alternatif yang paling mempengaruhi untuk menjaga kesehatan pada penggunaan konsumtif adalah kebutuhan sehari-hari.TKW lebih memprioritaskan kebutuhan sehari-hari dibandingkan dengan penggunaan konsumtif lainnya. Kemudian alokasi penggunaan terpenting kedua menurut mereka adalah kendaraan, disusul oleh bangun rumah dan yang trakhir adalah bayar utang. Setelah itu didapat hasil dari lamda maksimum dan CR menunjukan hasil adalah 0.06yang berarti nilai konsisten atau hasil dapat diterima.

Diagram batang pada penggunaan konsumtif kriteria pendidikan menunjukan bahwa, menurut hasil pembobotan 50 reponden alternatif yang paling mempengaruhi dalam pengeluaran rumah tangga pada penggunaan konsumtif adalah kebutuhan sehari-hari.TKW lebih memprioritaskan kebutuhan sehari-hari dibandingkan dengan penggunaan konsumtif lainnya. Kemudian alokasi penggunaan terpenting kedua menurut mereka adalah kendaraan, disusul oleh bangun rumah dan yang trakhir adalah bayar utang. Setelah itu didapat hasil dari lamda maksimum dan CR menunjukan hasil adalah 0.06 yang berarti nilai konsisten atau hasil dapat diterima.

\section{Penentuan Prioritas (Perangkingan) Penggunaan Produktif}

Pada kategori penggunaan produktif alokasi penggunaan remittance rata-rata TKW Desa Jorok Kecamatan Utan lebih memperioritaskan beli tanah. Budi (2004) mengatakan bahwa beli tanah adalah salah satu penggunaan produktif yang suatu saat akan membuat mereka sejahtera, beli tanah merupakan salah satu investasi masa depan yang semakin lama harganya semakin meningkat jauh dengan harga modal. Hasil dari jual tanah bisa dijadikan modal kembali ataupun untuk sistim jaga jaga apabila keluarga TKW berada pada keadaan mendesak. Yang terpenting kedua menurut TKW adalah Pendidikan sebagai salah satu alasan mereka berangkat keluar negeri terutama untuk TKW yang sudah berkeluarga dan mempunyai anak, Rizal (2017) pendidikan adalah salah satu modal awal untuk mencapai kesejahteraan dalam sumber daya manusia.yang ketiga adalah hewan ternak, TKW menganggap jika membeli hewan ternak bisa dijadikan tabungan yang sewaktu waktu bisa bertambah dengan berkembang biak, dalam penggunaan produktif ini tidak terlalu banyak TKW mengalokasikan dana remiitance untuk membeli hewan ternak dan yang trakhir tidak begitu diminati dan hanya sebagian kecil yang memilih usaha, sebagai salah satu tempat pengalokasian dana remittancekarena keluarga yang berada didaerah asal mempunyai pekerjaan yang sudah digeluti dari dulu dan salah satu sumber kehidupan mereka dari dulu yaitu petani.

\section{Penentuan Prioritas (Perangkingan) Penggunaan Konsumtif.}

pada kategori penggunaan konsumtif alokasi penggunaan remittance rata-rata TKW Desa Jorok Kecamatan Utan lebih mengutamakan kebutuhan sehari-hari sebagai salah satu alasan mereka berangkat keluar negeri, menurut mereka 
mencukupikebutuhan sehari-hari adalah alasan utama mereka berangkat ke luar negeri, kebutuhan sehari-hari seolah olah tidak bisa dibandingakn dengan penggunaan konsumtif lainnya (Dibyantoro,2018). yang kedua adalah bangun rumah, kebanyakan dari TKW sebelumnya sudah memiliki rumah turunan dari orang tua, tetapi kebanyakan TKW merenovasi ulang agar rumah mereka lebih layak untuk ditempati, adapun TKW yang membangun rumah adalah kebanyakan dari mereka yang belum berumah tangga dan membangun rumah impian untuk masa depan jika sudah kembali ke daerah asa (Budi,2004). yang ketiga adalah kendaraan, sebagian TKWjuga mengalokasikan dana remittance dipenggunaan konsumtif untuk membeli kendaraan, hal ini dilakukan karna kebanyakan dari TKW yang sudah berumah tangga dan kendaraan dibeli untuk anak yang bersekolah dan juga untuk mempermudah TKW berpergian baik yang belum menikah ataupun sudah menikah. dan yang trakhir pada penggunaan konsumtif adalah bayar hutang, sebagian kecil TKW juga memiliki hutang, rata rata hutang dari TKW relatif sedikit atau tidak terlalu banyak, mereka masih mampu untuk membayar jika pembayaran hutang sudah jatuh tempo.

Alokasi Penggunaan Produktif dan Konsumtif Remittance TKW Desa Jorok Kecamatan Utan.

\section{PENGGUNAAN PRODUKTIF DAN KONSUMTIF}

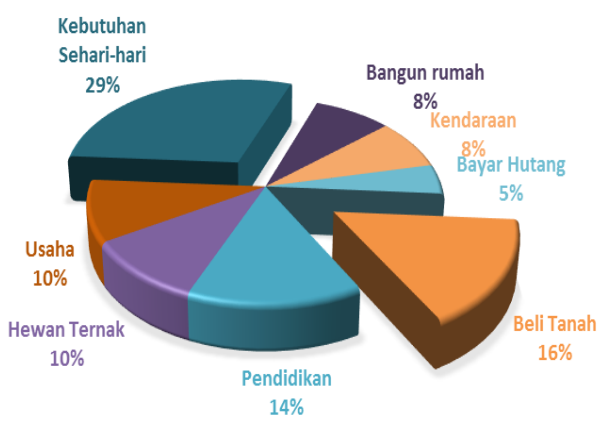

Dari persentase diagram diatas menunjukan bahwa Penggunaan remitan yang akan berdampak terhadapat tingkat kesejahteraan TKW Desa Jorok Kecamatan Utan adalah beli tanah dan kebutuhan sehari-hari. Dari hasil penelitian penggunaan produktif yang paling banyak mempengaruhi penggunaan lainnya menurut TKW Desa Jorok Kecamatan Utan adalah beli tanah. Beli tanah dapat menghasilkan nilai tambah baik secara material maupun non material dalam jangka waktu panjang. Rata-rata dari TKW ingin berinvestasi jenis tanah karna tanah merupakam salah satu jenis investasi properti yang menguntungkan kedepannya. Santoso (2004) dalam bukunya yang berjudul "Profit Berlipat dengan Investasi Tanah dan Rumah" mengatakan jika berinvetasi properti jenis tanah merupakan salah jenis investasi yang sangat menguntungkan karna harga tanah cenderung meningkat $20-25 \%$ pertahun dari harga modal, nilai tambah dari pegembanganya seperti pembangunan komersial yang mendatangkan keuntungan bagi pemiliknya seperti ruko, koskosan, kontrakan atau pengelolahan area pertanian dan juga proteksi daya beli terhadap investasi. Dan penggunaan untuk jangka waktu pendek yang berdampak pada tingkat kesejahteraan TKW adalah penggunaan konsumtif kebutuhan sehari-hari. TKW desa Jorok Kecamatan utan sebagian besar rata-rata dana remittance digunakan untuk kebutuhan sheahari-hari, penggunaan ini bersifat jangka pendek karna dana remittance tersebut hanya bersifat sementara yang sewaktu-waktu akan habis, dan hanya untuk bertahan hidup memenuhi kebutuhan sandang dan pangan keluarga TKW.

\section{PENUTUP}

\section{Kesimpulan}

Alokasi penggunaan remittance TKW Desa Jorok Kecamatan Utan berdasarkan dua penggunaan adalah penggunaan konsumtif dan penggunaan produktif. Pada penggunaan konsumtif TKW mengalokasikan dana remittance untuk kebutuhan sehari-hari, bangun rumah, membeli kendaraan dan bayar hutang. ada empat kategori pada masing-masing penggunaan yaitu berdasarkan Status perkawinan kawin dan belum kawin, berdasarkan penanggung jawab keuangan oleh suami dan keluarga lainnya, berdasrkan tempat tinggal TKW rumah sendiri dan rumah orang tua, berdasarkan status responden keluarga TKW dan mantan TKW. Terhitung dari semua kategori, Ada $81 \%$ dana remittance yang digunakan untuk Kebutuhan sehari-hari yang merupakan penggunaan dana remittance paling tinggi dari penggunaan remittance konsumtif lainnya, $17 \%$ untuk renovasi atau bangun rumah, $2 \%$ untuk membeli kendaraan dan terhitung tidak ada penggunaan rata-rata untuk penggunaan konsumtif bayar hutang, sementara untuk penggunaan produktif TKW mengalokasikan dana remittance untuk membeli tanah, pendidikan, hewan ternak dan usaha. Terhitung dari semua kategori Ada 60\% penggunaan dana remittance untuk pendidikan dan merupakan penggunann paling tinggi pada penggunaan produktif, 35\% penggunaan dana remittance untuk beli tanah, $4 \%$ untuk membeli hewan ternak dan $1 \%$ penggunaaan dana remittance untuk membangun usaha.

Dari hasil penelitian alokasi penggunaan remittance TKW bahwa pada penggunaan produktif yang paling banyak mempengaruhi jumlah pendapatan, perumahan, pendidikan, kesehatan dan pengeluaran rumah tangga di Desa Jorok Kecamatan 
Utan adalah beli tanah, beli tanah merupakan salah satu jenis investasi property dan akan berdampak pada kesejahteraan TKW dimasa mendatang.Santoso (2004) dalam bukunya yang berjudul "Profit Berlipat dengan Investasi Tanah dan Rumah" mengatakan jika berinvetasi properti jenis tanah merupakan salah jenis investasi yang sangat menguntungkan karna harga tanah cenderung meningkat 20-25\% pertahun dari harga modal, nilai tambah dari pegembanganya seperti pembangunan komersial yang mendatangkan keuntungan bagi pemiliknya seperti ruko, kos-kosan, kontrakan atau pengelolahan area pertanian dan juga proteksi daya beli terhadap investasi. yang kedua adalah pendidikan, dilihat dari status perkawinan TKW, 68\% TKW sudah menikah dan memiliki anak, ratarata tujuan utama mereka menjadi TKW adalah untuk membiayai pendidikan anak, Hal ini juga dapat merintis tingkat pendidikan yang lebih baik bagi penduduk Desa Jorok Kecamatan Utan ke

\section{REFERENSI}

Badan Pusat Statistik.2013. Kabupaten Sumbawa Dalam Angka (Regency inFigures BPS Sumbawa 2014.Sumbawa Besar.BPS Sumbawa (2014).Kabupaten Sumbawa Dalam Angka ( Regency in Figures BPS Sumbawa 2015.

(2015).Kabupaten Sumbawa Dalam Angka ( Regency in Figures BPS Sumbawa 2016. (2016).Kabupaten Sumbawa Dalam Angka ( Regency in Figures BPS Sumbawa 2017.

Badan Pusat Statistik.2009. Kecamatan Utan Dalam Angka (Regency in Figures BPS Sumbawa 2010.Sumbawa Besar.BPS Sumbawa.

2010).Kecamatan Utan Dalam Angka ( Regency in Figures BPS Sumbawa 2011. Sumbawa Besar

(2011).Kecamatan Utan Dalam Angka ( Regency in Figures BPS Sumbawa 2012.Sumbawa Besar.

BNP2TKI.2018.Data Penempatan Dan Perlindungan TKI Priode Bulan Desember Tahun 2017:Jakarta Selatan:BNP2TKI.

Haryati, Eni.2006. Remitansi Tenaga Kerja Indonesia Dampaknya Terhadap Inflasi Dan Kontribusinya Terhadap Peningkatan Kualitas Hidup Masyarakat. Universitas Dr. Soetomo Surabaya.

Mawardisyana.2013.Pengantar Penggunaan Aplikasi AHP (Analitycal HierarcyProces)http.//Mawardisyana.blo depannya. Pendidikan merupakan investasi jangka panjang bagi keluarga TKW, karena dengan

terpenuhinya pendidikan terhadap anak-anak mereka akan memungkinkan untuk dapat mengembangkan pola pikir mereka ke depannya, termasuk dalam berpikir untuk mencari ataupun Menciptakan pekerjaan yang lebih baik pada masanya nanti.Dan pada penggunaan konsumtif sebagian besar TKW atau 49\% TKW melakukan remittance untuk mencukupi kebutuhan sehari-hari keluarga yang berada di daerah asalnya, walupun bersifat jangka pendek pemenuhan kebutuhan sehari-hari adalah hal yang sangat penting untuk bertahan hidup dan mencukupi kebutuhan seharihari untuk beberapa waktu mendatang, tiga penggunaan tersebut akan sangat berdampak untuk kesejahteraan TKW kedepannya karna walupun tidak sekarang keuntungan dari penggunaan tersebut akan didapatkan di masa mendatang untuk keluarga TKW.

gspot.com/2013/04/pengantarahpl (Akses pada 4 november 2018)

Mantra.I.B.1986.Mobilitas Penduduk di Indonesia: Tokyo: National Institut for research Advanacment.

Mantra.1994.MobilitasSilkuler Dan Pembangunan Daerah Asal. Warta Demografi

Novia ,Ningsih. 2015. Peranan Perbankan syariah dalam mengimplementasikan keuangan inklusif di Indonesia :Jakarta. Universitas Indonesia.

Hadisumarto,Djunaidi.1995.Pasar Tenaga Kerja Indonesia (Khasus sektor kontruksi):Jakarta:Pustaka Pratama Grafiti.

Santoso,Budi.2004. Profit Berlipat Dengan InfestasITanah Dan Rumah.:Jakarta: lex Media Comporation.

Samsul,Ma'arif.2004. Pemanfaatan dana remitansi tenaga kerja Indoneisa di Kabupaten

Indramayu.Universitas IAIN Syekh Nurjati. Sugiharto,Eko.2007.IndikatorKesejahtera $n$ :Badan Pusat Statistik 2005.

Todaro.M.P.1969.Model Migrasi Tenaga Kerja dan Pengangguran Perkotaan di Negaranegarakurang berkembang

:Amerika.:AmericanEconomic Riview 